\title{
INCREASED NOVELTY-INDUCED MOTOR ACTIVITY AND REDUCED DEPRESSION-LIKE BEHAVIOR IN NEUROPEPTIDE Y (NPY)-Y4 RECEPTOR KNOCKOUT MICE
}

\author{
R. O. TASAN ${ }^{a}{ }^{\star}$, S. LIN $^{b}$, A. HETZENAUER ${ }^{c}$, N. SINGEWALD ${ }^{c}$, H. HERZOG ${ }^{b}$, and G. SPERK ${ }^{a},{ }^{*}$ \\ aDepartment of Pharmacology, Medical University Innsbruck, Peter-Mayr-Straße 1a, A-6020 \\ Innsbruck, Austria \\ bNeuroscience Research Program, Garvan Institute of Medical Research, NSW 2010 \\ Darlinghurst, Sydney, Australia \\ 'Department of Pharmacology and Toxicology, Institute of Pharmacy and Center of Molecular \\ Biosciences Innsbruck, University of Innsbruck, A-6020 Innsbruck, Austria
}

\begin{abstract}
There is growing evidence that neuropeptide Y (NPY) acting through Y1 and Y2 receptors has a prominent role in modulating anxiety- and depression-like behavior in rodents. However, a role of other Y-receptors like that of $\mathrm{Y} 4$ receptors in this process is poorly understood. We now investigated male Y2, Y4 single and Y2/Y4 double knockout mice in behavioral paradigms for changes in motor activity, anxiety and depression-like behavior. Motor activity was increased in Y2, Y4 and Y2/Y4 knockout mice under changing and stressful conditions, but not altered in a familiar environment. Y4 and Y2 knockout mice revealed an anxiolytic phenotype in the light/ dark test, marble burying test and in stress-induced hyperthermia, and reduced depression-like behavior in the forced swim and tail suspension tests. In Y2/Y4 double knockout mice, the response in the light/dark test and in the forced swim test was further enhanced compared with Y4 and Y2 knockout mice, respectively. High levels of Y4 binding sites were observed in brain stem nuclei including nucleus of solitary tract and area postrema. Lower levels were found in the medial amygdala and hypothalamus. Peripheral administration of pancreatic polypeptide (PP) induced Y4 receptor-dependent c-Fos expression in brain stem, hypothalamus and amygdala. PP released peripherally from the pancreas in response to food intake, may act not only as a satiety signal but also modulate anxiety-related locomotion.
\end{abstract}

\section{Keywords}

pancreatic polypeptide; neuropeptide Y; anxiety; depression; amygdala; area postrema

Pancreatic polypeptide (PP) is a 36 amino acid hormone, which is predominantly synthesized in type F islet cells of the pancreas (Berglund et al., 2003). Like neuropeptide $\mathrm{Y}$ (NPY) and peptide YY (PYY) it belongs to the so-called PP-fold peptide family (Berglund et al., 2003; Larhammar, 1996). Several $\mathrm{G}_{\mathrm{i} / \mathrm{o}}$ coupled receptors (Y1, Y2, Y4, Y5, y6) (Michel et al., 1998) are mediating actions of these peptides. Those of PP may be preferentially transduced by Y4 receptors (Berglund et al., 2001; Gehlert et al., 1996).

(C) 2009 IBRO. Published by Elsevier Ltd. All rights reserved.

*Corresponding author. Tel: +43-512-9003-71210; fax: +43-512-9003-73200. ramon.tasan@i-med.ac.at (R. O. Tasan), guenther.sperk@i-med.ac.at (G. Sperk). . 
Whereas high Y4 mRNA concentrations are present in the peripheral tissues, they are considerably lower in the brain (Bard et al., 1995; Lundell et al., 1997). PP is released into the circulation through a cholinergic, vagus-dependent mechanism upon ingestion of food, and consecutively regulates pancreas and gastric secretion, gall-bladder contraction and gastrointestinal motility (Asakawa et al., 1999). In mammalians, the distribution of the Y4 receptor has been investigated in brains of the rat and marmoset so far (Dumont et al., 1998). In the rat, Y4 receptors are primarily concentrated in the hypothalamus and in the brain stem (Fetissov et al., 2004; Lundell et al., 1997; Whitcomb et al., 1997). Data on Y4 receptor distribution in the mouse brain are not yet available.

In spite of their low abundance in the CNS, Y4 receptors seem to be involved in the regulation of metabolic processes. Thus, Y4 receptor knockout (KO) mice revealed signs of reduced weight gain, altered expression of gonadotropin-releasing hormone as well as increased male aggressive behavior (Asakawa et al., 2003; Sainsbury et al., 2002b, 2003). Furthermore, NPY another member of the PP-fold peptide family that is most abundantly expressed in neurons of the CNS exerts strong regulatory effects in emotion-related behaviors in rodents involving Y1 and Y2 receptors. Pressure injection of NPY and of Y1 receptor agonists, produced pronounced anxiolytic and antidepressant-like effects, notably in the amygdaloid nuclei (Heilig et al., 1993; Kask et al., 2002; Redrobe et al., 2002), whereas injection of Y2 receptor agonists into the basolateral amygdala was anxiogenic (Sajdyk et al., 2002).

We and others demonstrated that deletion of $\mathrm{Y} 2$ receptors results in pronounced anxiolytic and antidepressant-like effects (Carvajal et al., 2006; Redrobe et al., 2003; Tschenett et al., 2003). Recently Painsipp et al. (2008) demonstrated an anxiolytic and anti-depressant-like effect of $\mathrm{Y} 4$ receptor deletion in female mice.

In our present study we investigated male Y4 KO mice for changes in anxiety-like behavior in the elevated plus maze (Pellow et al., 1985; Lister, 1987; Rodgers and Dalvi, 1997)and the light/dark box (Bourin and Hascoet, 2003; Crawley and Goodwin, 1980) and depressionlike behavior in the forced swim test (Lucki, 1997; Petit-Demouliere et al., 2005; Porsolt et al., 1977) and tail suspension test (Cryan et al., 2005; Steru et al., 1985). In addition, basal and novelty-induced locomotor activity were examined by home-cage activity and in the open field test (Hall, 1934; Prut and Belzung, 2003), respectively. For differentiating anxiolytic-like behavior from changes in novelty-induced locomotor activity, we additionally used stress-induced hyperthermia (Borsini et al., 1989; Lecci et al., 1990; Olivier et al., 2003; Van der Heyden et al., 1997) and the marble burying test (Borsini et al., 2002; Broekkamp et al., 1986; Nicolas et al., 2006; Njung'e and Handley, 1991; Xu et al., 2004), that are independent or even inversely dependent on motor activity, respectively. In the marble burying test, selective suppression of marble burying is suggested to correlate with anxiolytic behavior (Borsini et al., 2002; Xu et al., 2004). Furthermore, for investigating whether effects of $\mathrm{Y} 4$ deletion are dependent or independent of $\mathrm{Y} 2$ receptormediated mechanisms, we conducted these behavioral tests concomitantly in $\mathrm{Y} 2$ single-KO and $\mathrm{Y} 2 / \mathrm{Y} 4$ double-KO mice.

For identifying possible anatomical sites integrating changes in emotional motor behaviors, we studied for the first time the distribution of Y4 receptors by receptor binding autoradiography in the mouse brain. Since in this study we observed high concentrations of $\mathrm{Y} 4$ receptors in brain areas accessible to peripheral blood circulation, such as the area postrema, we also investigated in wild-type and Y4 KO mice the effect of i.p. injection of $\mathrm{PP}$ on c-Fos expression in the brain. 


\section{EXPERIMENTAL PROCEDURES}

\section{Animals}

All experiments were conducted with adult male mice (10-16 weeks old, weighing 25-30 g) maintained on a C57BL/6-129SvJ background. They were housed in groups of three to five animals under standard laboratory conditions (12-h light/dark cycle, lights being on at 07:00 $\mathrm{h}$, food and water ad libitum). Generation of Y2, Y4 and Y2/Y4 KO animals has been described in detail previously (Sainsbury et al., 2002a,b). In brief, chimeric conditional-KO floxed mice $\left(\mathrm{Y} 2^{\text {lox/lox }}\right.$ or $\left.\mathrm{Y}^{1 \text { lox/lox }}\right)$ were crossed with oocyte-specific Cre-recombinase expressing C57BL/6 mice (Schwenk et al., 1995). Non-induced Y2 $2^{\text {lox/lox }}$ and Y $4^{\text {lox/lox }}$ mice were used as controls for $\mathrm{Y} 2 \mathrm{KO}$ and $\mathrm{Y} 4 \mathrm{KO}$ mice, respectively (see also below). As shown previously and verified in our present experiments, the phenotype of these controls did not differ from wild-type mice of the mixed C57BL/6-129SvJ background (Sainsbury et al., 2002a). Deletion of Y2 and Y4 receptors was confirmed in all mice used for the experiment by polymerase chain reaction (PCR) and agarose gel electrophoresis and demonstrated by in situ hybridization and receptor autoradiography (human (h) $\left.{ }^{125} \mathrm{I}\right]-\mathrm{PYY}_{3-36}$ for $\mathrm{Y} 2$ receptors, rat (r) [ $\left.{ }^{125} \mathrm{I}\right]-\mathrm{PP}$ for $\mathrm{Y} 4$ receptors) for randomly selected mice.

\section{Genotyping}

Genotypes of the mice were monitored as described previously (Sainsbury et al., 2002a). In brief, PCR was performed using the following primers for the Y2 receptor oligo-Y2C $\left(5^{\prime}\right.$ TTA ACA TCA GCT GGC CTA GC $3^{\prime}$ ), oligo-Y2D (5' GGA AGT CAA CTA CAC GAA TGG 3'), oligo-Y2E ( $5^{\prime}$ AGC ATC CAG AGA AGT GCA AC $\left.3^{\prime}\right)$ and for the Y4 receptor oligo-Y4A ( $5^{\prime}$ ATC CTT CCT GCC TCT ATG $3^{\prime}$ ), oligo-Y4B (5' GGA TAA TAC CTG AGT GGC $\left.3^{\prime}\right)$, oligo-Y4c ( $5^{\prime}$ GCA TCT GTA CTG AGT GGC $\left.3^{\prime}\right)$, with 40 cycles $94{ }^{\circ} \mathrm{C}$ for $45 \mathrm{~s}, 59^{\circ} \mathrm{C}$ for $45 \mathrm{~s}$ and $72{ }^{\circ} \mathrm{C}$ for $45 \mathrm{~s}$. DNA was loaded on a $2 \%$ agarose gel. Ethidium bromide-labeled bands were evaluated under UV light and monitored with a concomitantly run size marker. Using a combination of oligo- $\mathrm{Y} 2 \mathrm{C}$ and oligo-Y2D or oligo-Y4A and oligoY4B a floxed DNA sequence (Y2 ${ }^{\text {lox/lox }}$ mice: band corresponding to $365 \mathrm{bp}$; Y $4^{\text {lox/lox: }} 210$ bp) and a sequence corresponding to the intact $\mathrm{Y} 2$ or $\mathrm{Y} 4$ receptor gene could be detected (Y2 wild-type mice: $330 \mathrm{bp}$; Y4 wild-type mice: $350 \mathrm{bp}$ ), whereas oligo-Y2C and oligo$\mathrm{Y} 2 \mathrm{E}$ or oligo-Y4A and oligo-Y4C were used to demonstrate the deletion of the $\mathrm{Y} 2$ receptor or Y4 receptor, respectively (Y2 KO mice: $250 \mathrm{bp}$; Y4 KO mice: $290 \mathrm{bp}$ ); (for details see (Sainsbury et al., 2002a,b).

\section{Behavioral experiments}

Procedures involving animals and their care were conducted in conformity with international laws and policies (EEC Council Directive 86/609, OJ L 358, 1, December 12, 1987; Guide for the Care and Use of Laboratory Animals, U.S. National Research Council, 1996). They were approved by the Austrian Ministry of Science. All efforts were taken to minimize the number of animals used and their suffering. Prior to behavioral testing all animals were allowed to habituate to the test room for at least $24 \mathrm{~h}$. All behavioral tests (except stressinduced hyperthermia) were conduced between 08:00 and 12:00. The respective setups had been validated pharmacologically in-house before. Behavioral testing was performed in groups of 8 to 10 mice per genotype and always replicated in separate experiments using naïve cohorts of mice. In all cases experiments revealed the same outcome of behavioral changes. In the initial set of experiments, Y4 and Y2 KO mice were compared with their respective controls ( $\mathrm{Y} 4^{\mathrm{lox} / \mathrm{lox}}, \mathrm{Y} 2^{\mathrm{lox} / \mathrm{lox}}$ mice, respectively are referred to as "controls"). The floxed mice ( $\left.\mathrm{Y} 4^{\mathrm{lox} / \mathrm{lox}}, \mathrm{Y} 2^{\mathrm{lox} / \mathrm{lox}}\right)$ were considered as the most appropriate controls, since KO mice used for the study were derived from these strains. In the repetition experiments, Y4 and $\mathrm{Y} 2 / \mathrm{Y} 4$, or $\mathrm{Y} 2$ and $\mathrm{Y} 2 / \mathrm{Y} 4 \mathrm{KO}$ were tested against control mice. In separate experiments $\mathrm{Y} 2^{\mathrm{lox} / \mathrm{lox}}$ and $\mathrm{Y} 4^{\text {lox/lox }}$ mice were also compared with WT mice on the same mixed 
background and no difference between controls (Y4 $\left.4^{\text {lox/lox }}, \mathrm{Y}^{\text {lox/lox }}\right)$ and WT mice was observed in any of the performed tests (data not shown). All experiments were done in a blinded and randomized fashion. The genotype of all mice was verified after each experiment.

\section{Tests of motor activity}

Home cage activity-Activity measurements were performed in the home cage of mice for $60 \mathrm{~h}$. Mice were single-housed in standard cages with food and water ad libitum. Movements of the mice were determined by an infrared sensor throughout light and dark phases (TSE LabMaster InfraMot, TSE Systems, Bad Homburg, Germany). After a 24 h acclimatization period, cumulative activity measurements were evaluated in the subsequent $24 \mathrm{~h}$ period. Our setting allowed concomitant testing of four KO mice and four controls. Testing was performed during the weekend to avoid any disturbance. Data obtained at two successive weekends were pooled for final evaluation of home cage behavior.

Open field test-The open field test was conducted as previously described (Tschenett et al., 2003). The setup for the open field test consisted of four individual gray plastic boxes $(50 \times 50 \times 30 \mathrm{~cm})$ illuminated with 150 lux. Boxes were arranged in a square and two controls and two KO mice were tested simultaneously. Analysis was done using the VideoMot2 system (TSE Systems). For evaluation of motor behavior each box was virtually divided in a $34 \times 34$ center zone, and a surrounding $8 \mathrm{~cm}$ border belt. $\mathrm{KO}$ mice and controls were placed individually into the center of a box and their behavior was tracked for $10 \mathrm{~min}$.

\section{Tests of anxiety}

Elevated plus maze-The elevated plus maze was performed as previously described (Pellow et al., 1985; Lister, 1987). The apparatus was obtained from TSE Systems. It consisted of an elevated plus ( $74 \mathrm{~cm}$ above the floor) with two opposing open arms $(30 \times 5$ $\mathrm{cm})$ and two opposing closed arms $(30 \times 5 \times 14 \mathrm{~cm})$. At the beginning mice were placed on the center platform $(5 \times 5 \mathrm{~cm})$ facing an open arm. Illumination of the open arms was 80 lux. Testing time was 5 min and arm entry was defined when the mouse had placed all four paws into an arm. Analysis was performed by a VideoMot2 system (TSE Systems).

Light/dark test-For the light/dark test we followed the procedure described by Crawley and Goodwin (1980). The apparatus consisted of a dark plastic compartment covering $1 / 3$ $(16 \times 50 \mathrm{~cm})$ and a bright compartment covering $2 / 3(34 \times 50 \mathrm{~cm})$ of the testing area. The two parts were connected by a central opening $(7 \times 7 \mathrm{~cm})$ on floor level. Illumination in the light compartment was 400 lux, that of the dark compartment 1 lux. Mice were placed individually into the dark compartment facing away from the opening. The behavior of each mouse was then tracked for $10 \mathrm{~min}$ and analyzed by VideoMot2 system (TSE Systems).

Stress-induced hyperthermia-The test was performed between 13:30 and 15:00 h. Mice were carried to the experimental room and put individually into holding cages. After an adaptation period of $90 \mathrm{~min}$ basal temperature was obtained with a rectal mouse probe (Van der Heyden et al., 1997). The probe was $1.5 \mathrm{~mm}$ in diameter and inserted $20 \mathrm{~mm}$ into the mouse rectum, while the animal was gently restrained manually. Before insertion the probe was dipped into silicone cream and maintained in the rectum until stable values were obtained (20 s). Temperature was measured to the nearest $0.1{ }^{\circ} \mathrm{C}$ (Omega HH147 RS-232, Newport Electronics GmbH, Deckenpfronn, Germany). After 10 min the second value was determined to calculate the stress-induced hyperthermia $(\Delta \mathrm{T}=\mathrm{T} 2-\mathrm{T} 1)$.

Defensive marble burying-Mice were kept in the experimental room for adaptation for at least 120 min (Njung'e and Handley, 1991). The experimental setup consisted of 
polyethylene cages $(38 \times 22 \times 16 \mathrm{~cm})$ containing 24 glass marbles $(1.5 \mathrm{~cm}$ diameter $)$ evenly spaced on $5 \mathrm{~cm}$ deep rodent sawdust bedding. The cage was closed with an even metal grid on top of which an infrared sensor was mounted for activity measurements. No food or water was present during the $30 \mathrm{~min}$ observation period. At the end of the experiment all marbles covered at least two-thirds by sawdust were determined. Motor activity was recorded using an infrared sensor (TSE LabMaster InfraMot, TSE Systems) during the whole test.

\section{Tests of depression-like behavior}

Porsolt's forced swim test-The forced swim test was conducted as described previously (Petit-Demouliere et al., 2005; Porsolt et al., 1977). In brief, mice were placed in an open glass cylinder (diameter $12 \mathrm{~cm}$, height $24 \mathrm{~cm}$, water level $16 \mathrm{~cm}$ ) containing fresh tap water of $23-25^{\circ} \mathrm{C}$. The duration of the test was $6 \mathrm{~min}$. The last 4 min were analyzed in 1 min bins. Floating was defined when the mouse performed only those movements required to keep its head above the water surface. The test was videotaped and evaluated by two different experimenters blind to the genotype of the mice.

Tail suspension test-The tail suspension test was performed as described previously (Mayorga and Lucki, 2001; Steru et al., 1985). Mice were suspended by the tail to a bar in a box open to the camera at the front $(28 \times 28 \times 40 \mathrm{~cm})$ and the behavior was recorded for a 6 min period. The experiment was evaluated independently by two trained observers blind to the genotype of the mice. Immobility was defined as the absence of limb movement.

\section{Histochemical methods}

In situ hybridization for $\mathrm{Y} 2$ receptors-Mice were killed by exposure to $\mathrm{CO}_{2}$ gas. Brains were rapidly removed and frozen by immersion in $-70{ }^{\circ} \mathrm{C}$ isopentane (Merck, Darmastadt, Germany). Coronal $20 \mu \mathrm{m}$ sections were cut using a cryostat-microtome (Carl Zeiss AG, Vienna, Austria), and thaw-mounted on adhesive, silane-coated slides. These sections were either used for in situ hybridization or receptor autoradiography.

In situ hybridization of Y2 receptor mRNA was done essentially as described previously (Schwarzer et al., 1998). Two oligonucleotides complementary to nucleotides 711-762: 5' GCT CTC CAG GTG GTA GAC AAT GCA ACG ATG GCG GTC CAG AGC AAT GAC TGT C 3' and 1415-1458: 5' CCA TGT GCT TTC ACA CCT GTG TCC TTA CAC ATT GGTAGC CTC CG $3^{\prime}$ ) of the mouse Y2 receptor were labeled with $\left[{ }^{35}\right.$ S]thio-dATP by deoxynucleotidyltranferase (Roche, Mannheim, Germany). Sections were incubated concomitantly with both ${ }^{35}$ S-labeled oligonucleotides for $18 \mathrm{~h}$ and then washed stringently and exposed to Biomax films (Kodak, France).

Receptor autoradiographies for Y2 and Y4 receptors-For Y2 and Y4 receptor autoradiographies [ $\left.{ }^{125} \mathrm{I}\right] \mathrm{hPYY}_{3-36}$ and $\left[{ }^{125} \mathrm{I}\right] \mathrm{rPP}$ were used as radioligands, respectively. Assays were performed as described previously (Furtinger et al., 2001). rPP and hPYY 3-36 were freshly radiolabeled using the chloramine-T method and purified by high performance liquid chromatography. Coronal $20 \mu \mathrm{m}$ sections (see above) from control and Y4 KO mouse brains were preincubated in $200 \mathrm{ml}$ modified Krebs-Henseleit buffer (in mM: $118 \mathrm{NaCl}, 4.8$ $\mathrm{KCl}, 1.3 \mathrm{MgSO}_{4}, 1.2 \mathrm{CaCl}_{2}, 1.2 \mathrm{KH}_{2} \mathrm{PO}_{4}, 15 \mathrm{NaHCO}_{3}, 50$ glucose, 10 Tris-HCl, $\mathrm{pH} 7.4$ ) for $60 \mathrm{~min}$ at room temperature. Incubation was performed in Hellendahl jars with $50 \mathrm{ml}$ of the same buffer supplemented with $0.1 \%$ bovine serum albumin and $0.05 \%$ bacitracin and $50 \mathrm{pM}$ of the respective radioligand for $120 \mathrm{~min}$. For termination of the reaction sections were dipped twice in ice cold Krebs-Henseleit buffer, washed $30 \mathrm{~s}$ in the same buffer, dipped in deionized ice cold water and rapidly dried under a stream of cold air. The slides labeled with $\left[{ }^{125} \mathrm{I}\right] \mathrm{hPYY}$ 3-36 and $\left[{ }^{125} \mathrm{I}\right] \mathrm{rPP}$ were then exposed to Biomax films (Kodak) for 7 
and 21 days, respectively. Unspecific binding was determined by incubating subsequent sections in the presence of $1 \mu \mathrm{M}$ NPY.

\section{c-Fos expression in the amygdala after peripherally applied PP}

Injections of PP-Twelve wild type and eight Y4 KO mice, fasted overnight, were injected i.p. with PP $(1.0 \mathrm{mg} / \mathrm{kg}$ ) or vehicle (phosphate-buffered saline, PBS) in a volume of $1 \mathrm{ml} / \mathrm{kg}$ between 10:00-12:00. At $30 \mathrm{~min}$ and $90 \mathrm{~min}$ after i.p. injection mice were deeply anesthetized with ketamine/xylazine (100 mg/kg and $20 \mathrm{mg} / \mathrm{kg}$ from Parke Davis-Pfizer, Sydney, Australia and Bayer AG, Leverkusen, Germany, respectively) and perfused via the left ventricle with $25 \mathrm{ml}$ PBS following by ice-cold 4\% paraformaldehyde in PBS. Brains were immediately removed and placed in $4 \%$ paraformaldehyde for 30 min then in PBS containing $30 \%$ sucrose overnight.

c-Fos immunohistochemistry-Coronal slices of $30 \mu \mathrm{m}$ thickness were mounted on slides and washed in $1 \% \mathrm{H}_{2} \mathrm{O}_{2}$ in $50 \%$ alcohol for 20 min to abolish endogenous peroxidase activity. Sections were incubated overnight at room temperature with the primary antibody, rabbit-anti-mouse c-Fos (Santa Cruz Biotechnology Inc., Santa Cruz, CA, USA), diluted at 1:4,000 in PBS containing 0.1\% Triton X-100. After three 10-min washes in PBS-Triton, sections were incubated with the biotinylated secondary anti-rabbit antibody (SigmaAldrich, St. Louis, MO, USA), diluted 1:250 in PBS for $3 \mathrm{~h}$. Sections were washed three times for 10 min each in PBS and then incubated with avidin-biotin-peroxidase Vectastain ${ }^{\circledR}$ (Vector Laboratories, Burlingame, CA, USA) for $30 \mathrm{~min}$ at room temperature. Sections were rinsed in PBS and treated with diaminobenzidine (Dako, Carpinteria, CA, USA) for $5 \mathrm{~min}$. Slides were rinsed in water and dehydrated by passing them through increasing concentrations of ethanol and then in xylene before mounting.

Quantification of c-Fos positive neurons-Sections were screened for visualization of c-Fos-like immunoreactivity (Fos-IR) neurons using an Axiophot microscope. In regions differences in Fos-IR neurons were readily apparent, Fos-positive nuclei were counted following the area outline. Every third section was counted for each nucleus for quantification of Fos-IR neurons. According to the atlas of mouse brain in stereotaxic coordinates by Paxinos and Franklin (2001). The value represents an average of Fos-IR neurons cells were based on relative size and dark stained nuclei. Comparisons were made between two groups stained at the same time. The average of cell counts in each nucleus was determined from both left and right sides, and then all groups were pooled for final analysis.

\section{Statistical analysis}

Statistical analysis was performed using GraphPad Prism software (Prism 4 for MacIntosh, GraphPad Software Inc., San Diego, CA, USA). Effects of genotype was assessed by oneway analysis of variance (ANOVA) followed by Newman-Keuls test for post hoc analysis of group differences. Comparison of two groups was done by Student's $t$-test. All data for the analysis of c-Fos expression in the brain were assessed by factorial ANOVA followed by Fisher's or contrasts post hoc tests, using StatView version 4.5 or Super-ANOVA (Abacus Concepts Inc., CA, USA). Group data are expressed as mean \pm S.E.M. Statistical significance was set at $P<0.05$.

\section{RESULTS}

\section{Distribution of $\mathrm{Y} 2$ and $\mathrm{Y} 4$ receptors}

In situ hybridization and receptor autoradiography revealed high levels of Y2 receptor mRNA and binding sites in various limbic brain areas, notably in the amygdala and the hippocampus, as previously described (Dumont et al., 1998; Gackenheimer et al., 2001; 
Parker and Herzog, 1999). In Y2 and Y2/Y4 KO mice Y2 receptor was absent on mRNA and protein level (data not shown). As shown in Fig. 1, Y4 receptor binding was particularly enriched in different brain stem nuclei, like the nucleus of solitary tract, nucleus ambiguous (Fig. 1A), facial nucleus, area postrema and the inferior olive (Fig. 1B). Lower levels of Y4 receptors were present in the medial amygdala and in the ventromedial hypothalamus (Fig. $1 \mathrm{~F})$. The specificity of this binding was supported by the fact, that no signal was detected on sections from Y4 and Y2/Y4 KO mice (Fig. 1C).

\section{Motor activity tests}

Home cage activity-In order to assess general activity of Y2, Y4 and Y2/Y4 receptor KO mice, we determined the basal locomotion in the home cage. As shown in Fig. 2 there was no effect of genotype in cumulative home cage activity measured during $24 \mathrm{~h}$ (activity counts in thousands: Y2 KO: $20.85 \pm 2.28$, control: $20.45 \pm 2.16, P=0.91$; Y4 KO: $16.52 \pm 3.39$, control: $17.26 \pm 1.87, P=0.85$; Y $2 / \mathrm{Y} 4 \mathrm{KO}: 16.52 \pm 2.90$, control: $18.39 \pm 1.52, P=0.58, n=8 /$ group) In contrast, Y4 KO mice displayed a higher activity during the dark phase of the first $24 \mathrm{~h}$, when compared with control animals. In Y2/Y4 receptor KO mice, a second activity peak was observed before the onset of the light phase.

Open field test-The explorative drive and motor behavior in a novel environment was investigated in the open field paradigm (Fig. 3). Total distance, number of center entries and number of rearings were taken as parameters of activity in an unfamiliar, potentially aversive environment. Statistical analysis by one-way ANOVA indicated a genotype-related difference in total distance $\left(F_{2,52}=34.75, P<0.0001\right.$ for controls vs. Y2 and $\mathrm{Y} 2 / \mathrm{Y} 4 \mathrm{KO}$ mice; $F_{2,29}=22.66, P<0.0001$ for controls vs. Y4 and Y2/Y4 KO mice), number of center entries $\left(F_{2,52}=18.75, P<0.0001\right.$ for controls vs. Y 2 and $\mathrm{Y} 2 / \mathrm{Y} 4 \mathrm{KO}$ mice; $F_{2,29}=34.15, P<0.0001$ for controls vs. Y4 and Y2/Y4 KO mice) and vertical activity $\left(F_{2,52}=3.42, P=0.0002\right.$ for controls vs. $\mathrm{Y} 2$ and $\mathrm{Y} 2 / \mathrm{Y} 4 \mathrm{KO}$ mice; $F_{2,29}=7.19, P=0.0028$ for controls vs. $\mathrm{Y} 4$ and $\mathrm{Y} 2 / \mathrm{Y} 4$ $\mathrm{KO}$ mice). Post hoc analysis of the data revealed that Y2, Y4 and Y2/Y4 KO mice displayed increased explorative drive. Similarly all three groups of KO mice spent a significantly increased time in the center of the arena compared with controls, as revealed by ANOVA $\left(F_{2,53}=6.55, P<0.0001\right.$ for controls vs. Y2 and Y2/Y4 KO mice; $F_{2,29}=14.00, P<0.0001$ for controls vs. $\mathrm{Y} 4$ and $\mathrm{Y} 2 / \mathrm{Y} 4 \mathrm{KO}$ mice) and post hoc test.

\section{Anxiety- and depression-related behaviors}

Light/dark test-The light/dark test of anxiety indicated anxiolytic phenotypes for all three KO lines, Y2, Y4 and Y2/Y4 receptor KO mice (Fig. 4). All three groups of receptor $\mathrm{KO}$ mice showed an increased percentage of time spent in the light compartment $\left(F_{2,23}=7.50, P=0.0029\right.$ for controls vs. $\mathrm{Y} 2$ and $\mathrm{Y} 2 / \mathrm{Y} 4 \mathrm{KO}$ mice; $F_{2,23}=9.75, P=0.0008$ for controls vs. Y4 and Y2/Y4 KO mice). Post hoc analysis revealed for Y4 KO mice $(P<0.05)$ and $\mathrm{Y} 2 / \mathrm{Y} 4 \mathrm{KO}(P<0.001)$ an increased time spent in the light compartment compared with controls. Also the time spent in the light box by Y2/Y4 double KO $(P<0.05)$ was increased compared with $\mathrm{Y} 4 \mathrm{KO}$ mice. The number of transitions was higher $\left(F_{2,23}=6.90, P=0.0029\right.$ for controls vs. Y2 and Y2/Y4 KO mice; $F_{2,23}=7.56, P=0.0028$ for controls vs. Y4 and Y2/ Y4 KO mice), when compared with controls. The distance traveled in the light compartment (Fig. 4B) was increased in all three groups of KO mice $\left(F_{2,23}=19.45, P<0.0001\right.$ for controls vs. Y2 and Y2/Y4 KO mice; $F_{2,23}=16.19, P<0.0001$ for controls vs. Y4 and Y2/Y4 KO mice), whereas no difference was observed analyzing the distance traveled in the dark compartment (Fig. 4C) $\left(F_{2,23}=1.45, P=0.25\right.$ for controls vs. Y2 and Y2/Y4 KO mice; $F_{2,23}=1.29, P=0.29$ for controls vs. Y4 and Y2/Y4 KO mice).

Elevated plus maze-In the elevated plus maze (Fig. 5), Y2 and Y2/Y4 KO mice spent more time on the open arms $\left(F_{2,54}=10.41, P=0.0001\right.$ for controls vs. $\mathrm{Y} 2$ and $\mathrm{Y} 2 / \mathrm{Y} 4 \mathrm{KO}$ 
mice; $F_{2,45}=13.25, P<0.0001$ for controls vs. Y4 and Y2/Y4 KO mice) and showed a higher percentage of open arm entries compared with control animals $\left(F_{2,54}=5.92, P=0.0043\right.$ for controls vs. Y2 and Y2/Y4 KO mice; $F_{2,45}=10.58, P=0.0002$ for controls vs. Y4 and Y2/Y4 $\mathrm{KO}$ mice), as indicated by post hoc analysis. $\mathrm{Y} 2$ and $\mathrm{Y} 2 / \mathrm{Y} 4 \mathrm{KO}$ mice, but not $\mathrm{Y} 4 \mathrm{KO}$ mice revealed an increased number of closed arm entries $\left(F_{2,54}=6.68, P=0.0023\right.$ for controls vs. $\mathrm{Y} 2$ and $\mathrm{Y} 2 / \mathrm{Y} 4 \mathrm{KO}$ mice). The total distance traveled was, however, increased in all three KO lines $\left(F_{2,54}=11.63, P<0.0001\right.$ for controls vs. Y2, and Y2/Y4 KO mice; $F_{2,45}=16.52$, $P<0.0001$ for controls vs. Y4 and Y2/Y4 KO mice).

Stress-induced hyperthermia-To obtain anxiety-related parameters that are independent of motor activity we performed stress-induced hyperthermia in $\mathrm{Y} 2 \mathrm{KO}, \mathrm{Y} 4 \mathrm{KO}$, $\mathrm{Y} 2 / \mathrm{Y} 4 \mathrm{KO}$ and control mice. Stress induced by the method per se (measurement of rectal temperature) led to a significant increase in temperature $(\Delta \mathrm{T})$. One-way ANOVA revealed a genotype-related difference in $\Delta \mathrm{T}\left(F_{2,39}=7.34, P=0.002\right)$. Post hoc test showed that $\mathrm{Y} 4 \mathrm{KO}$ $(P<0.01)$ but not $\mathrm{Y} 2 / \mathrm{Y} 4 \mathrm{KO}(P>0.05)$ exhibited a reduced $\Delta \mathrm{T}$ compared with controls (Fig. $6 \mathrm{~A})$. At the same time, a significant increase of basal temperature was observed in $\mathrm{Y} 4 \mathrm{KO}$ $\left(38.5 \pm 0.17{ }^{\circ} \mathrm{C}\right)$ compared with $\mathrm{Y} 2 / \mathrm{Y} 4 \mathrm{KO}\left(37.6 \pm 0.27^{\circ} \mathrm{C}\right)$ and wild type controls $(37.6 \pm 0.18$ $\left.{ }^{\circ} \mathrm{C}\right)$ as shown by one-way ANOVA $\left(F_{2,39}=6.53, P=0.0036\right)$ and post hoc test $(P<0.01$ for $\mathrm{Y} 4$ $\mathrm{KO}$ vs. controls and $P<0.01$ for Y4 KO vs. Y2/Y4 KO). Similarly, Y2 KO (Fig. 6B) mice displayed a significant reduction of $\Delta \mathrm{T}$ compared with control mice (controls: $1.2 \pm 0.10^{\circ} \mathrm{C}$, Y2 KO: $0.8 \pm 0.16^{\circ} \mathrm{C} ; P=0.02$ ). There was no difference in basal temperature between $\mathrm{Y} 2$ $\mathrm{KO}\left(37.3 \pm 0.21^{\circ} \mathrm{C}\right)$ and control $\left(37.5 \pm 0.20^{\circ} \mathrm{C}\right)$ mice.

Marble burying-Enhanced exploration in approach avoidance tests could be secondary to increased general activity. For investigating this aspect, we performed a marble burying test, in which reduced anxiety correlates with a decreased number of marbles buried by the mouse in the bedding of the cage. As shown in Fig. 7A, Y4 KO mice buried significantly fewer marbles than control mice (controls: 9.75 \pm 2.25 , Y4 KO: 3.00 $\pm 1.60 ; P=0.028$ ). Assessment of motor activity revealed increased activity of $\mathrm{Y} 4 \mathrm{KO}$ mice during the first part of the test compared with controls. ANOVA indicated that this effect was dependent on genotype $\left(F_{1,70}=6.35\right)$ and that there was a significant interaction between genotype and time $\left(F_{6,70}=2.34\right)$. The difference between genotype was apparent after 10 and $15 \min (5-10$ min: $P<0.05 ; 10-15$ min: $P<0.01)$ as determined by Bonferroni post hoc test. Similarly, Y2/ Y4 KO (Fig. 7B) buried significantly fewer marbles during the $30 \mathrm{~min}$ testing period (controls: $16.13 \pm 2.07$; Y2/Y4 KO: $6.50 \pm 2.11, P=0.006$ ). No difference was observed in general motor activity between $\mathrm{Y} 2 / \mathrm{Y} 4 \mathrm{KO}$ and control mice in this test. The known anxiolytic phenotype of Y2 KO mice was confirmed in the marble-burying test (Fig. 7C) (controls: $13.50 \pm 2.56$, Y2 KO: $6.63 \pm 1.89, P=0.048$ ). There was no difference in general activity during the 30 min testing period between $\mathrm{Y} 2 \mathrm{KO}$ and controls.

Forced swim test and tail-suspension test-In order to investigate depression-like behavior in a stressful and inescapable situation we performed Porsolt's forced swim test and the tail suspension test (Fig. 8). In the forced swim test, a significant decrease in floating time was apparent in $\mathrm{Y} 4, \mathrm{Y} 2$ and $\mathrm{Y} 2 / \mathrm{Y} 4$ receptor $\mathrm{KO}$ mice, as revealed by one-way ANOVA followed by post hoc analysis $\left(F_{2,25}=27.81, P<0.0001\right.$ for controls versus $\mathrm{Y} 2$ and $\mathrm{Y} 2 / \mathrm{Y} 4 \mathrm{KO}$ mice; $F_{2,29}=68.42, P<0.0001$ for controls vs. $\mathrm{Y} 4 \mathrm{KO}$ and $\mathrm{Y} 2 / \mathrm{Y} 4$ double $\mathrm{KO}$ mice). In addition, post hoc analysis showed a lower immobility time of $\mathrm{Y} 2 / \mathrm{Y} 4 \mathrm{KO}$ compared with Y2 single KO mice (Fig. 8A). The tail-suspension test revealed comparable effects on stress-coping ability after $\mathrm{Y} 4$ and $\mathrm{Y} 2 / \mathrm{Y} 4$ receptor deletion as the forced swim test. During the 6 min testing period, Y4 KO, Y2 KO and Y2/Y4 double-KO mice spent a significantly reduced time in immobility $\left(F_{2,25}=8.53, P=0.0014\right.$ for controls vs. Y2 $\mathrm{KO}$ and 
Y2/Y4 double KO mice; $F_{2,29}=15.70, P<0.0001$ for controls vs. Y4 KO and Y2/Y4 double KO mice).

Y4 receptor-mediated activation of amygdala neurons-To investigate a possible influence of peripherally released PP on central mechanisms integrating emotion-related behavior, we used i.p. injection of the endogenous Y4 preferring ligand PP and analyzed the anatomical distribution of expression of the early neuronal activation marker c-Fos in the brain. Brains were isolated $30 \mathrm{~min}$ and $90 \mathrm{~min}$ after i.p. PP for identification of directly and indirectly activated brain regions, respectively and processed for immunohistochemistry. In addition to strong c-Fos expression (Table 1) in the area postrema there was a significant increase in c-Fos activation specifically in the arcuate nucleus, nucleus of solitary tract and medial amygdala compared with saline-injected control mice $30 \mathrm{~min}$ after i.p. injection of PP (Fig. 9A and B). Expression was more pronounced in the paraventricular nucleus, in the ventromedial hypothalamus and in the lateral hypothalamic area after 90 min than after 30 min. (Table 1). Consistent with a Y4 specific action no increase in c-Fos immunoreactivity can be seen in these same areas of i.p. PP-injected Y4 KO mice (Fig. 9C and D).

\section{DISCUSSION}

Our experiments using behavioral testing in male mice from three different $\mathrm{KO}$ lines revealed two major changes in phenotype related to Y4 receptor deletion: 1) increased motor activity under stressful and novel conditions and 2) changes in emotional behavior as indicated by reduced depression-like behavior and in anxiety-related behavior in the light/ dark test, marble-burying test and stress-induced hyperthermia (but not elevated plus maze). In several instances, emotion-related behavioral changes were more pronounced in the $\mathrm{Y} 2 /$ $\mathrm{Y} 4$ double $\mathrm{KO}$ mice than in $\mathrm{Y} 4$ or $\mathrm{Y} 2 \mathrm{KO}$ mice, suggesting that $\mathrm{Y} 4$-mediated mechanisms in integrating emotional behavior are coordinated with $\mathrm{Y} 2$ receptor activity.

\section{Novelty-induced motor activity}

Motor activity was investigated 1) under baseline, non-aversive conditions by assessing home cage activity during three consecutive light/dark cycles and 2) in a potentially stressful environment using the novel open field test. In the familiar environment, such as the home cage, there was no significant difference in general motor activity between any genotypes. The increased activities displayed by Y4 KO mice during the first dark phase, and the second peak of activity at the onset of the light phase in Y2/Y4 double KO mice, presumably reflect increased arousal responses induced by the change in conditions. These behavioral aspects were confirmed by investigating the mice in a novel open field, where Y4, Y2 and Y2/Y4 KO mice revealed increased horizontal and vertical activity compared with controls.

\section{Anxiety-related behavior}

Whereas $\mathrm{Y} 2 \mathrm{KO}$ mice and $\mathrm{Y} 2 / \mathrm{Y} 4$ double $\mathrm{KO}$ mice revealed an anxiolytic phenotype in all tests (except stress-induced hyperthermia), evidence toward reduced anxiety in Y4 KO mice was ambiguous. Y4 KO mice showed less anxiety-like behavior in the light/dark and marble burying test, but not in the elevated plus maze. The additional increase in time spent and distance traveled by $\mathrm{Y} 2 / \mathrm{Y} 4 \mathrm{KO}$ mice in the lit compartment of the light/dark test compared with Y4 and Y2 KO mice, respectively suggests the involvement of coordinated mechanisms mediated by $\mathrm{Y} 2$ and $\mathrm{Y} 4$ receptors during emotional challenge. Most importantly, all three $\mathrm{KO}$ lines showed a longer total distance traveled in the elevated plus maze, as well as an increased distance traveled in the lit compartment of the light/dark box. Since motor activity was not increased in the dark compartment of the light/dark box, this phenomenon seems to be dependent on stressful novel conditions. 
For further investigating the contribution of novelty-induced motor activity in the exploration/avoidance tasks, we investigated stress-induced hyperthermia test in Y4, Y2/Y4 and Y2 KO mice an anxiety test that is independent of motor behavior. This test seems to have face, construct and predictive validity in modeling anxiety-related autonomous responses (Olivier et al., 2003). The observed reduction in the hyperthermic response $(\Delta \mathrm{T})$ points toward reduced anxiety in $\mathrm{Y} 4$ and $\mathrm{Y} 2 \mathrm{KO}$ mice. However, since the basal temperature was higher in $\mathrm{Y} 4 \mathrm{KO}$ mice than in $\mathrm{WT}$ and $\mathrm{Y} 2 / \mathrm{Y} 4$ double $\mathrm{KO}$, we cannot exclude a ceiling effect in the body temperature of Y4 KO mice. In addition, hypothalamic structures involved in temperature control are directly or indirectly targeted by NPY and PP (Parker and Herzog, 1999). Temperature control is a multi-factorial phenomenon. Therefore the implication of the stress-induced hyperthermia data may be limited. Interestingly, there was no difference in stress-induced body temperature in $\mathrm{Y} 2 / \mathrm{Y} 4 \mathrm{KO}$ mice compared with controls. However, while basal temperature is unaltered in $\mathrm{Y} 2 / \mathrm{Y} 4 \mathrm{KO}$ mice, there is evidence for facultative thermogenesis in this mouse strain (Sainsbury et al., 2003, 2006). Together with altered sympathetic signaling, increased thyrotropin releasing hormone mRNA levels in the paraventricular nucleus of the hypothalamus could be a cause for changes in thermoregulation in Y2/Y4 KO mice (Ribeiro et al., 2001; Sainsbury et al., 2003, 2006; Silva and Larsen, 1983).

For investigating further the possible dependence of emotion-related behavior on locomotion, we performed the marble burying test that is inversely dependent on motor activity. In this test, selective suppression in burying marbles (considered by the mice to be potentially aversive) is investigated as a measure of anxiety-like behavior (Njung'e and Handley, 1991). In contrast to other paradigms, this test is not based on increased exploration as an index of anxiolytic-like effects (Cryan and Holmes, 2005). Predictive validity of this alternative behavioral test was obtained by the fact that both benzodiazepines, and selective 5-HT reuptake inhibitors are able to reduce the number of marbles buried (Borsini et al., 2002). Moreover, the marble burying test has been applied successfully in evaluating the anxiolytic property of compounds, which increase locomotion at the same time (Xu et al., 2004). Results from this test indicate both, novelty-induced hyperlocomotion and reduced anxiety-related behavior in Y4 receptor KO mice. Similar as in the open field test, also in this test Y4 KO mice revealed increased general motor activity during the first $15 \mathrm{~min}$. Nevertheless the number of marbles buried was reduced in Y4 KO mice. This test points to independent mechanisms leading to changes in novelty-induced locomotion and emotional behavior after Y4 receptor deletion.

\section{Reduced depression-like behavior}

For investigating depression-like behavior in the mice, we performed the tail suspension and forced swim tests, both models based on paradigms testing the ability of the mice to cope with stressful conditions. These tests have been pharmacologically validated to be sensitive to treatment with antidepressant drugs as well as for phenotypic changes in transgenic mice (Cryan et al., 2002; Cryan and Mombereau, 2004). Significantly reduced immobility in both tests as observed in all three KO mouse lines, mimics effects of antidepressant treatment and therefore indicates reduced depression-like behavior. Although both tests are quite similar in design, they seem to differ in biological changes underling the observed behavior. In contrast to the traditional forced swim test, the tail suspension test detects the efficacy of a broad spectrum of antidepressant treatments (Cryan et al., 2002; Lucki, 1997), including selective 5-HT reuptake inhibitors and it is independent of swimming ability or thermoregulation (Cryan and Mombereau, 2004; Cryan et al., 2005). Since both tests revealed profound suppression of immobility, we suppose that deletion of Y4, Y2 and Y2/ $\mathrm{Y} 4$ receptors produces a stable antidepressant effect. Changes in $\mathrm{Y} 2 \mathrm{KO}$ mice were even more pronounced after combined deletion of $\mathrm{Y} 2$ and $\mathrm{Y} 4$ receptors, indicating coordinated 
mechanisms mediated by the two receptors in reducing depression-like behavior. Changes in depression-related behavior are independent of the influence of sexual hormones since we observed similar changes also in female mice (Painsipp et al., 2008). It is interesting to note, that female Y4 KO mice revealed a clear anxiolytic effect on the elevated plus maze.

\section{Considerations on central Y4 receptors mediating actions of peripherally released PP}

Our experiments indicate that in wild-type mice Y4 receptors mediate depressant- and anxiogenic-like behavior and reduced motor activity, tightly linked to novel, unfamiliar conditions. This is supported by a recent report suggesting an anxiogenic phenotype in PP over-expressing mice (Ueno et al., 2007). The effects of Y4 receptors seem to be similarly potent as those mediated by $\mathrm{Y} 2$ receptors and, since they are partially additive, they appear to be coordinated with Y2 receptor-mediated mechanisms. Both, Y2 and Y4 receptors predominantly interact with Gi and Gq resulting in inhibition of cAMP accumulation (Freitag et al., 1995; Voisin et al., 2000; Walker et al., 1997). Local injections of NPY agonists (Kask et al., 2002) and site-specific deletion of Y2 receptors in amygdaloid nuclei performed by our group demonstrated an important role of the amygdala in Y1 and Y2 receptor-mediated mechanisms of NPY on emotional behavior (Tasan et al., 2007). Y1 receptors mediate their action including anxiolysis primarily at postsynaptic sites, whereas Y2 receptors are mostly located presynaptically on NPY/GABA neurons or at terminals of glutaminergic axons (Parker and Balasubramaniam, 2008), where they inhibit the release of classical transmitters (Adewale et al., 2005; Chen et al., 1997; Greber et al., 1994). The site and mode of actions through Y4 receptors are not clear yet. Considering the similar behavioral effects of $\mathrm{Y} 2$ and $\mathrm{Y} 4$ receptor deletion and the similar signaling pathways used by Y2 and Y4 receptors it may be possible that Y4 receptors, either activated by NPY or by $\mathrm{PP}$, are located presynaptically on terminals in brain stem or hypothalamic nuclei, resulting in an inhibition of transmitter release (Acuna-Goycolea et al., 2005). Interestingly, Y4 receptors have been also found in human astrocyte cultures, indicating a possible role of glial cells in Y4 receptor actions (Abounader et al., 1999).

Our present receptor autoradiographic studies revealed low, but significant concentrations of Y4 receptor binding in the amygdala and in the ventromedial hypothalamus. Also Y4 mRNA was observed in these areas of the rat indicating that the receptors may be expressed in local neurons (Whitcomb et al., 1990; Trinh et al., 1996; Parker and Herzog, 1999). All these observations are compatible with Y4 receptor-mediated mechanisms integrating emotional behavior in these brain areas. Furthermore, we found considerably higher levels of Y4 receptors in brain stem nuclei, like the nucleus tractus solitarius, nucleus ambiguous, the inferior olive and in the area postrema, that are mainly involved in the regulation of autonomous functions and in the vegetative response to emotions.

Studies in cell lines expressing recombinant Y4 receptors indicate that PP may be the primary PP-fold peptide acting on Y4 receptors (Berglund et al., 2001; Gehlert et al., 1996). PP is there about 100 times more potent than NPY or PYY in inhibiting binding of $\left[{ }^{125} \mathrm{I}\right] \mathrm{Leu}^{31} \mathrm{Pro}^{34} \mathrm{PYY}$ and $\left[{ }^{125} \mathrm{I}\right] \mathrm{PP}$ to Y4 binding sites (Yan et al., 1996; Gehlert et al., 1997). Nevertheless affinities of NPY and PYY $(\mathrm{kB}=1 \mathrm{nM})$ are still in a physiological/ pharmacological range and affinities of PP-fold peptides to Y4 receptors may be different in brain tissue (DiMaggio et al., 1985). Among the PP-fold peptides, only NPY is expressed in sufficiently high concentrations. NPY is thought to act primarily through Y1, Y2 and Y5 receptors to which it binds at affinities of 20-100 pM and exerts its prominent effects on anxiety and stress-coping behavior in rats and mice (Heilig, 2004). In spite of its apparently relatively low affinity to Y4 receptors, NPY appears to be the only reasonable candidate as a ligand for central Y4 receptors and NPY can still activate Y4 receptors at nanomolar concentration (Bard et al., 1995; McTigue and Rogers, 1995). 
On the other hand, in vivo, peripheral PP is able to access PP-binding receptors in the area postrema, which circumvents the blood-brain barrier (Whitcomb et al., 1990), and a central action of PP has been established after local injection (McTigue and Rogers, 1995). Radiolabeled PP accumulates presumably at the high abundant Y4 receptors in the area postrema (Dumont et al., 2007). Thus PP released upon ingestion of food by vagal stimulation from pancreatic islets of Langhans into the circulation may be a regulator of emotional behavior by primarily acting on central Y4 receptors in areas outside the bloodbrain barrier.

An earlier study reported no difference regarding anxiety behavior after single injections of $\mathrm{mPP}$ into the ventricles (Asakawa et al., 1999). In contrast, repeated i.p. injection of mouse $\mathrm{PP}$ in fatty lizer Shoinogy $o b / o b$ obese mice resulted in an anxiolytic effect (Asakawa et al., 2003). This is in contrast to the anxiogenic effect seen in PP over-expressing mice (Ueno et al., 2007), supporting the anxiolytic effect of Y4 receptor deletion seen in the light/dark test in our present study. Differences in injection protocols (acute versus chronic, i.c.v. versus i.p.) and possible compensational effects or location of the transgene(s) in PP overexpressing mice may explain differing observations, but leave the site and mechanisms of Y4-receptor-mediated effects on emotional behavior still open.

Consistent with this is the observation made in our present study where i.p. administration of PP specifically increased c-Fos expression in addition to brain stem nuclei and arcuate nucleus also in the medial amygdala. These experiments indicate that also peripherally applied PP (acting e.g. in the area postrema or in the lateral hypothalamus upon Y4 receptors) may indirectly result in an activation of the medial amygdala and other nuclei related to integration of emotions, linking induction of satiety with potential changes in anxiety-related behavior (Ebner et al., 2004). The regionally different time course of c-Fos expression in different brain nuclei suggests activation of different pathways by PP treatment. At the same time, NPY release in the medial amygdala could exert synergistic effects upon Y4 receptors present in this brain nucleus. Interestingly, lesions of the area postrema, containing high concentrations of Y4 receptors, result in increased NPY expression in the amygdala and reduced anxiety (Miller et al., 2002). Although the exact relation of the nucleus tractus solitarius with anxiety is not established, it is interesting to note that different anxiogenic drugs can activate c-Fos expression in this brain area (Singewald and Sharp, 2000). There exists also an interplay between the nucleus tractus solitarius containing high concentrations of Y4 receptors with the central nucleus of the amygdala, since it receives a dense GABA-ergic input from this brain area (Saha et al., 2000). Y4 receptors in the solitary nucleus are therefore ideally positioned for influencing GABA-ergic signals from the amygdala complex, the main structure of emotional behavior. Intriguing are also the possible roles of Y4 receptors in vagal nuclei of the brain stem where they are highly enriched. These nuclei are crucially involved in the regulation of autonomous functions presumably including the vagally regulated release of PP in the periphery.

\section{CONCLUSION}

Our data show an increase in novelty-induced locomotion and reduced depression-related behavior in male $\mathrm{Y} 4$ receptor $\mathrm{KO}$ mice. The effects of $\mathrm{Y} 4$ and $\mathrm{Y} 2$ receptor deletion on emotional behavior may be additive as suggested by the phenotype of Y2/Y4 double KO mice. High concentrations of Y4 receptors in mouse brain areas, like the nucleus of solitary tract or the area postrema suggest an involvement of Y4 receptors in the modulation of emotionally driven autonomic responses, which are likely to influence the final step of emotional output. 


\section{Acknowledgments}

The work was supported by the Austrian Science Research Funds (S10202 and S10204) and NHMRC grant \# 354109 .

\section{Abbreviations}

$\begin{array}{ll}\text { ANOVA } & \text { analysis of variance } \\ \text { Fos-IR } & \text { c-Fos-like immunoreactivity } \\ \text { KO } & \text { knockout } \\ \text { NPY } & \text { neuropeptide Y } \\ \text { PBS } & \text { phosphate-buffered saline } \\ \text { PCR } & \text { polymerase chain reaction } \\ \text { PP } & \text { pancreatic polypeptide } \\ \text { PYY } & \text { peptide YY }\end{array}$

\section{REFERENCES}

Abounader R, Elhusseiny A, Cohen Z, Olivier A, Stanimirovic D, Quirion R, Hamel E. Expression of neuropeptide Y receptors mRNA and protein in human brain vessels and cerebromicrovascular cells in culture. J Cereb Blood Flow Metab. 1999; 19:155-163. [PubMed: 10027771]

Acuna-Goycolea C, Tamamaki N, Yanagawa Y, Obata K, van den Pol AN. Mechanisms of neuropeptide Y, peptide YY, and pancreatic polypeptide inhibition of identified green fluorescent protein-expressing GABA neurons in the hypothalamic neuroendocrine arcuate nucleus. J Neurosci. 2005; 25:7406-7419. [PubMed: 16093392]

Adewale AS, Macarthur H, Westfall TC. Neuropeptide Y induced modulation of dopamine synthesis in the striatum. Regul Pept. 2005; 129:73-78. [PubMed: 15927700]

Asakawa A, Inui A, Ueno N, Fujimiya M, Fujino MA, Kasuga M. Mouse pancreatic polypeptide modulates food intake, while not influencing anxiety in mice. Peptides. 1999; 20:1445-1448. [PubMed: 10698120]

Asakawa A, Inui A, Yuzuriha H, Ueno N, Katsuura G, Fujimiya M, Fujino MA, Niijima A, Meguid MM, Kasuga M. Characterization of the effects of pancreatic polypeptide in the regulation of energy balance. Gastroenterology. 2003; 124:1325-1336. [PubMed: 12730873]

Bard JA, Walker MW, Branchek TA, Weinshank RL. Cloning and functional expression of a human Y4 subtype receptor for pancreatic polypeptide, neuropeptide Y, and peptide YY. J Biol Chem. 1995; 270:26762-26765. [PubMed: 7592911]

Berglund MM, Hipskind PA, Gehlert DR. Recent developments in our understanding of the physiological role of PP-fold peptide receptor subtypes. Exp Biol Med (Maywood). 2003; 228:217244. [PubMed: 12626767]

Berglund MM, Lundell I, Eriksson H, Soll R, Beck-Sickinger AG, Larhammar D. Studies of the human, rat, and guinea pig Y4 receptors using neuropeptide $\mathrm{Y}$ analogues and two distinct radioligands. Peptides. 2001; 22:351-356. [PubMed: 11287089]

Borsini F, Lecci A, Volterra G, Meli A. A model to measure anticipatory anxiety in mice? Psychopharmacology (Berl). 1989; 98:207-211. [PubMed: 2502791]

Borsini F, Podhorna J, Marazziti D. Do animal models of anxiety predict anxiolytic-like effects of antidepressants? Psychopharmacology (Berl). 2002; 163:121-141. [PubMed: 12202959]

Bourin M, Hascoet M. The mouse light/dark box test. Eur J Pharmacol. 2003; 463:55-65. [PubMed: 12600702]

Broekkamp CL, Rijk HW, Joly-Gelouin D, Lloyd KL. Major tranquillizers can be distinguished from minor tranquillizers on the basis of effects on marble burying and swim-induced grooming in mice. Eur J Pharmacol. 1986; 126:223-229. [PubMed: 2875886] 
Carvajal C, Dumont Y, Herzog H, Quirion R. Emotional behavior in aged neuropeptide Y (NPY) Y2 knockout mice. J Mol Neurosci. 2006; 28:239-245. [PubMed: 16691011]

Chen X, DiMaggio DA, Han SP, Westfall TC. Autoreceptor-induced inhibition of neuropeptide Y release from PC-12 cells is mediated by Y2 receptors. Am J Physiol. 1997; 273:H1737-H1744. [PubMed: 9362238]

Crawley J, Goodwin FK. Preliminary report of a simple animal behavior model for the anxiolytic effects of benzodiazepines. Pharmacol Biochem Behav. 1980; 13:167-170. [PubMed: 6106204]

Cryan JF, Holmes A. The ascent of mouse: advances in modelling human depression and anxiety. Nat Rev Drug Discov. 2005; 4:775-790. [PubMed: 16138108]

Cryan JF, Markou A, Lucki I. Assessing antidepressant activity in rodents: recent developments and future needs. Trends Pharmacol Sci. 2002; 23:238-245. [PubMed: 12008002]

Cryan JF, Mombereau C. In search of a depressed mouse: utility of models for studying depressionrelated behavior in genetically modified mice. Mol Psychiatry. 2004; 9:326-357. [PubMed: 14743184]

Cryan JF, Mombereau C, Vassout A. The tail suspension test as a model for assessing antidepressant activity: review of pharmacological and genetic studies in mice. Neurosci Biobehav Rev. 2005; 29:571-625. [PubMed: 15890404]

DiMaggio DA, Chronwall BM, Buchanan K, O’Donohue TL. Pancreatic polypeptide immunoreactivity in rat brain is actually neuropeptide Y. Neuroscience. 1985; 15:1149-1157. [PubMed: 3900804]

Dumont Y, Jacques D, Bouchard P, Quirion R. Species differences in the expression and distribution of the neuropeptide Y Y1, Y2, Y4, and Y 5 receptors in rodents, guinea pig, and primates brains. J Comp Neurol. 1998; 402:372-384. [PubMed: 9853905]

Dumont Y, Moyse E, Fournier A, Quirion R. Distribution of peripherally injected peptide YY ([125I] PYY (3-36)) and pancreatic polypeptide ([125I] hPP) in the CNS: enrichment in the area postrema. J Mol Neurosci. 2007; 33:294-304. [PubMed: 17952639]

Ebner K, Rupniak NM, Saria A, Singewald N. Substance P in the medial amygdala: emotional stresssensitive release and modulation of anxiety-related behavior in rats. Proc Natl Acad Sci U S A. 2004; 101:4280-4285. [PubMed: 15024126]

Fetissov SO, Kopp J, Hokfelt T. Distribution of NPY receptors in the hypothalamus. Neuropeptides. 2004; 38:175-188. [PubMed: 15337370]

Freitag C, Svendsen AB, Feldthus N, Lossl K, Sheikh SP. Coupling of the human Y2 receptor for neuropeptide $\mathrm{Y}$ and peptide $\mathrm{YY}$ to guanine nucleotide inhibitory proteins in permeabilized SMSKAN cells. J Neurochem. 1995; 64:643-650. [PubMed: 7830057]

Furtinger S, Pirker S, Czech T, Baumgartner C, Ransmayr G, Sperk G. Plasticity of Y1 and Y2 receptors and neuropeptide $Y$ fibers in patients with temporal lobe epilepsy. J Neurosci. 2001; 21:5804-5812. [PubMed: 11466452]

Gackenheimer SL, Schober DA, Gehlert DR. Characterization of neuropeptide Y Y1-like and Y2-like receptor subtypes in the mouse brain. Peptides. 2001; 22:335-341. [PubMed: 11287087]

Gehlert DR, Schober DA, Beavers L, Gadski R, Hoffman JA, Smiley DL, Chance RE, Lundell I, Larhammar D. Characterization of the peptide binding requirements for the cloned human pancreatic polypeptide-preferring receptor. Mol Pharmacol. 1996; 50:112-118. [PubMed: 8700103]

Gehlert DR, Schober DA, Gackenheimer SL, Beavers L, Gadski R, Lundell I, Larhammar D. $\left[{ }^{125} \mathrm{I}\right]$ Leu31, Pro34-PYY is a high affinity radioligand for rat PP1/Y4 and Y1 receptors: evidence for heterogeneity in pancreatic polypeptide receptors. Peptides. 1997; 18:397-401. [PubMed: 9145427]

Greber S, Schwarzer C, Sperk G. Neuropeptide Y inhibits potassium-stimulated glutamate release through Y2 receptors in rat hippocampal slices in vitro. Br J Pharmacol. 1994; 113:737-740. [PubMed: 7858862]

Hall CS. Emotional behavior in the rat: I. Defecation and urination as measures of individual differences in emotionality. J Comp Psychol. 1934; 1:385-403.

Heilig M. The NPY system in stress, anxiety and depression. Neuropeptides. 2004; 38:213-224. [PubMed: 15337373] 
Heilig M, McLeod S, Brot M, Heinrichs SC, Menzaghi F, Koob GF, Britton KT. Anxiolytic-like action of neuropeptide $\mathrm{Y}$ : mediation by $\mathrm{Y} 1$ receptors in amygdala, and dissociation from food intake effects. Neuropsychopharmacology. 1993; 8:357-363. [PubMed: 8099792]

Kask A, Harro J, von Horsten S, Redrobe JP, Dumont Y, Quirion R. The neurocircuitry and receptor subtypes mediating anxiolytic-like effects of neuropeptide Y. Neurosci Biobehav Rev. 2002; 26:259-283. [PubMed: 12034130]

Larhammar D. Evolution of neuropeptide Y, peptide YY and pancreatic polypeptide. Regul Pept. 1996; 62:1-11. [PubMed: 8738876]

Lecci A, Borsini F, Volterra G, Meli A. Pharmacological validation of a novel animal model of anticipatory anxiety in mice. Psychopharmacology (Berl). 1990; 101:255-261. [PubMed: 1971957]

Lister RG. The use of a plus-maze to measure anxiety in the mouse. Psychopharmacology (Berl). 1987; 92:180-185. [PubMed: 3110839]

Lucki I. The forced swimming test as a model for core and component behavioral effects of antidepressant drugs. Behav Pharmacol. 1997; 8:523-532. [PubMed: 9832966]

Lundell I, Berglund MM, Starback P, Salaneck E, Gehlert DR, Larhammar D. Cloning and characterization of a novel neuropeptide Y receptor subtype in the zebrafish. DNA Cell Biol. 1997; 16:1357-1363. [PubMed: 9407007]

Mayorga AJ, Lucki I. Limitations on the use of the C57BL/6 mouse in the tail suspension test. Psychopharmacology (Berl). 2001; 155:110-112. [PubMed: 11374330]

McTigue DM, Rogers RC. Pancreatic polypeptide stimulates gastric acid secretion through a vagal mechanism in rats. Am J Physiol. 1995; 269:R983-R987. [PubMed: 7503326]

Michel MC, Beck-Sickinger A, Cox H, Doods HN, Herzog H, Larhammar D, Quirion R, Schwartz T, Westfall T. XVI International Union of Pharmacology recommendations for the nomenclature of neuropeptide Y, peptide YY, and pancreatic polypeptide receptors. Pharmacol Rev. 1998; 50:143150. [PubMed: 9549761]

Miller CC, Holmes PV, Edwards GL. Area postrema lesions elevate NPY levels and decrease anxietyrelated behavior in rats. Physiol Behav. 2002; 77:135-140. [PubMed: 12213511]

Nicolas LB, Kolb Y, Prinssen EP. A combined marble burying-locomotor activity test in mice: a practical screening test with sensitivity to different classes of anxiolytics and antidepressants. Eur J Pharmacol. 2006; 547:106-115. [PubMed: 16934246]

Njung'e K, Handley SL. Evaluation of marble-burying behavior as a model of anxiety. Pharmacol Biochem Behav. 1991; 38:63-67. [PubMed: 2017455]

Olivier B, Zethof T, Pattij T, van Boogaert M, van Oorschot R, Leahy C, Oosting R, Bouwknecht A, Veening J, van der Gugten J, Groenink L. Stress-induced hyperthermia and anxiety: pharmacological validation. Eur J Pharmacol. 2003; 463:117-132. [PubMed: 12600705]

Painsipp E, Wultsch T, Edelsbrunner ME, Tasan RO, Singewald N, Herzog H, Holzer P. Reduced anxiety-like and depression-related behavior in neuropeptide Y Y4 receptor knockout mice. Genes Brain Behav. 2008; 7(5):532-542. [PubMed: 18221379]

Parker RM, Herzog H. Regional distribution of Y-receptor subtype mRNAs in rat brain. Eur J Neurosci. 1999; 11:1431-1448. [PubMed: 10103138]

Parker SL, Balasubramaniam A. Neuropeptide Y Y2 receptor in health and disease. Br J Pharmacol. 2008; 153:420-431. [PubMed: 17828288]

Paxinos, G.; Franklin, KBJ. The mouse brain in stereotaxic coordinates. 2nd ed.. Academic Press; San Diego: 2001.

Pellow S, Chopin P, File SE, Briley M. Validation of open:closed arm entries in an elevated plus-maze as a measure of anxiety in the rat. J Neurosci Methods. 1985; 14:149-167. [PubMed: 2864480]

Petit-Demouliere B, Chenu F, Bourin M. Forced swimming test in mice: a review of antidepressant activity. Psychopharmacology (Berl). 2005; 177:245-255. [PubMed: 15609067]

Porsolt RD, Le Pichon M, Jalfre M. Depression: a new animal model sensitive to antidepressant treatments. Nature. 1977; 266:730-732. [PubMed: 559941]

Prut L, Belzung C. The open field as a paradigm to measure the effects of drugs on anxiety-like behaviors: a review. Eur J Pharmacol. 2003; 463:3-33. [PubMed: 12600700] 
Redrobe JP, Dumont Y, Fournier A, Quirion R. The neuropeptide Y (NPY) Y1 receptor subtype mediates NPY-induced antidepressant-like activity in the mouse forced swimming test. Neuropsychopharmacology. 2002; 26:615-624. [PubMed: 11927186]

Redrobe JP, Dumont Y, Herzog H, Quirion R. Neuropeptide Y (NPY) Y2 receptors mediate behaviour in two animal models of anxiety: evidence from Y2 receptor knockout mice. Behav Brain Res. 2003; 141:251-255. [PubMed: 12742262]

Ribeiro MO, Carvalho SD, Schultz JJ, Chiellini G, Scanlan TS, Bianco AC, Brent GA. Thyroid hormone-sympathetic interaction and adaptive thermogenesis are thyroid hormone receptor isoformspecific. J Clin Invest. 2001; 108:97-105. [PubMed: 11435461]

Rodgers RJ, Dalvi A. Anxiety, defence and the elevated plusmaze. Neurosci Biobehav Rev. 1997; 21:801-810. [PubMed: 9415905]

Saha S, Batten TF, Henderson Z. A GABAergic projection from the central nucleus of the amygdala to the nucleus of the solitary tract: a combined anterograde tracing and electron microscopic immunohistochemical study. Neuroscience. 2000; 99:613-626. [PubMed: 10974425]

Sainsbury A, Baldock PA, Schwarzer C, Ueno N, Enriquez RF, Couzens M, Inui A, Herzog H, Gardiner EM. Synergistic effects of Y2 and Y4 receptors on adiposity and bone mass revealed in double knockout mice. Mol Cell Biol. 2003; 23:5225-5233. [PubMed: 12861009]

Sainsbury A, Bergen HT, Boey D, Bamming D, Cooney GJ, Lin S, Couzens M, Stroth N, Lee NJ, Lindner D, Singewald N, Karl T, Duffy L, Enriquez R, Slack K, Sperk G, Herzog H. Y2Y4 receptor double knockout protects against obesity due to a high-fat diet or Y1 receptor deficiency in mice. Diabetes. 2006; 55:19-26. [PubMed: 16380472]

Sainsbury A, Schwarzer C, Couzens M, Fetissov S, Furtinger S, Jenkins A, Cox HM, Sperk G, Hokfelt T, Herzog H. Important role of hypothalamic Y2 receptors in body weight regulation revealed in conditional knockout mice. Proc Natl Acad Sci U S A. 2002a; 99:8938-8943. [PubMed: 12072562]

Sainsbury A, Schwarzer C, Couzens M, Jenkins A, Oakes SR, Ormandy CJ, Herzog H. Y4 receptor knockout rescues fertility in ob/ob mice. Genes Dev. 2002b; 16:1077-1088. [PubMed: 12000791]

Sajdyk TJ, Schober DA, Smiley DL, Gehlert DR. Neuropeptide Y-Y2 receptors mediate anxiety in the amygdala. Pharmacol Biochem Behav. 2002; 71:419-423. [PubMed: 11830176]

Schwarzer C, Kirchmair E, Sperk G. Metabotropic glutamate receptors mediate activation of NPY-Y2 receptor expression in the rat dentate gyrus. Neuroreport. 1998; 9:2347-2351. [PubMed: 9694226]

Schwenk F, Baron U, Rajewsky K. A cre-transgenic mouse strain for the ubiquitous deletion of loxPflanked gene segments including deletion in germ cells. Nucleic Acids Res. 1995; 23:5080-5081. [PubMed: 8559668]

Silva JE, Larsen PR. Adrenergic activation of triiodothyronine production in brown adipose tissue. Nature. 1983; 305:712-713. [PubMed: 6633638]

Singewald N, Sharp T. Neuroanatomical targets of anxiogenic drugs in the hindbrain as revealed by Fos immunocytochemistry. Neuroscience. 2000; 98:759-770. [PubMed: 10891619]

Steru L, Chermat R, Thierry B, Simon P. The tail suspension test: a new method for screening antidepressants in mice. Psychopharmacology (Berl). 1985; 85:367-370. [PubMed: 3923523]

Tasan RO, Weger S, Heilbronn R, Nguyen NK, Singewald N, Herzog H, Sperk G. Experiments to localize the site for the anxiogenic action of NPY mediated by Y2 receptors in the mouse brain. BMC Pharmacol. 2007; 7(Suppl 2):A14.

Trinh T, van Dumont Y, Quirion R. High levels of specific neuropeptide Y/pancreatic polypeptide receptors in the rat hypothalamus and brainstem. Eur J Pharmacol. 1996; 318:R1-R3. [PubMed: 9007534]

Tschenett A, Singewald N, Carli M, Balducci C, Salchner P, Vezzani A, Herzog H, Sperk G. Reduced anxiety and improved stress coping ability in mice lacking NPY-Y2 receptors. Eur J Neurosci. 2003; 18:143-148. [PubMed: 12859347]

Ueno N, Asakawa A, Satoh Y, Inui A. Increased circulating cholecystokinin contributes to anorexia and anxiety behavior in mice overexpressing pancreatic polypeptide. Regul Pept. 2007; 141:8-11. [PubMed: 17306894]

Van der Heyden JA, Zethof TJ, Olivier B. Stress-induced hyperthermia in singly housed mice. Physiol Behav. 1997; 62:463-470. [PubMed: 9272651] 
Voisin T, Goumain M, Lorinet AM, Maoret JJ, Laburthe M. Functional and molecular properties of the human recombinant $\mathrm{Y} 4$ receptor: resistance to agonist-promoted desensitization. J Pharmacol Exp Ther. 2000; 292:638-646. [PubMed: 10640301]

Walker MW, Smith KE, Bard J, Vaysse PJ, Gerald C, Daouti S, Weinshank RL, Branchek TA. A structure-activity analysis of the cloned rat and human Y4 receptors for pancreatic polypeptide. Peptides. 1997; 18:609-612. [PubMed: 9210181]

Whitcomb DC, Puccio AM, Vigna SR, Taylor IL, Hoffman GE. Distribution of pancreatic polypeptide receptors in the rat brain. Brain Res. 1997; 760:137-149. [PubMed: 9237528]

Whitcomb DC, Taylor IL, Vigna SR. Characterization of saturable binding sites for circulating pancreatic polypeptide in rat brain. Am J Physiol. 1990; 259:G687-G691. [PubMed: 2221079]

Xu YL, Reinscheid RK, Huitron-Resendiz S, Clark SD, Wang Z, Lin SH, Brucher FA, Zeng J, Ly NK, Henriksen SJ, de Lecea L, Civelli O. Neuropeptide S: a neuropeptide promoting arousal and anxiolytic-like effects. Neuron. 2004; 43:487-497. [PubMed: 15312648]

Yan H, Yang J, Marasco J, Yamaguchi K, Brenner S, Collins F, Karbon W. Cloning and functional expression of cDNAs encoding human and rat pancreatic polypeptide receptors. Proc Natl Acad Sci U S A. 1996; 93:4661-4665. [PubMed: 8643460] 

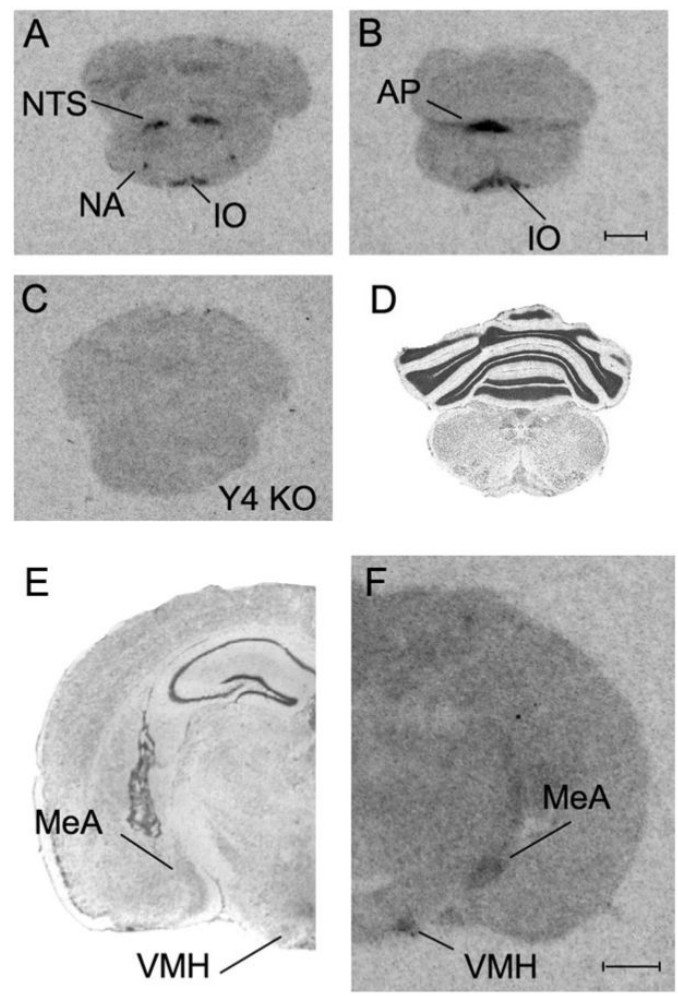

Fig. 1.

Autoradiographs of $\left[{ }^{125} \mathrm{I}\right] \mathrm{rPP}$ binding in coronal sections of the mouse brain. High levels of PP binding sites were observed in the nucleus of solitary tract (NTS), nucleus ambiguus

(NA), the inferior olive (IO) and the area postrema (AP). (A, B) PP binding sites seen in Y4 KO mice $(\mathrm{C})$, moderate levels of $\mathrm{Y} 4$ receptors were observed in the posteriordorsal division of the medial amygdala (MeA) and in the ventromedial hypothalamus (VMH). (F) In D and E Nissl-stained sections adjacent to those in A and F are depicted. Scale bars $=1 \mathrm{~mm}$. 

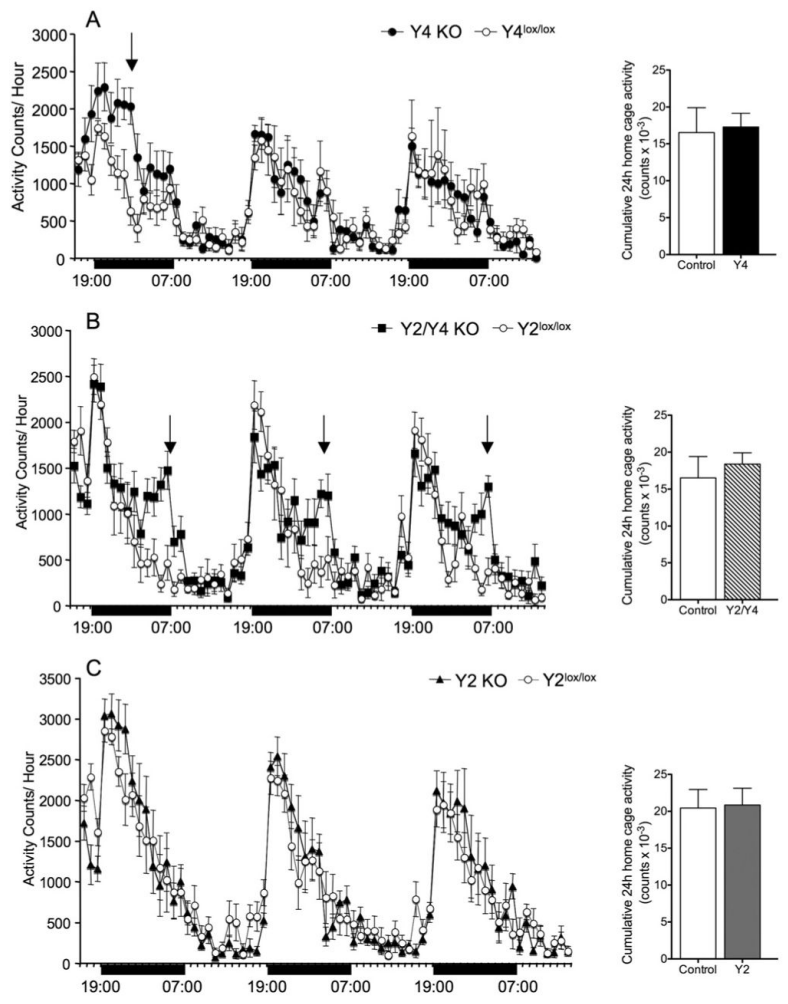

Fig. 2.

Home cage activity of Y4 KO, Y2 KO and Y2/Y4 double-KO mice compared with Y $2^{\text {lox/lox }}$ and $\mathrm{Y} 4^{\text {lox/lox }}$ mice as controls. (A) There is no difference in home cage activity between $\mathrm{Y} 4$ $\mathrm{KO}$ and $\mathrm{Y} 4^{\text {lox/lox }}$ mice in cumulative $24 \mathrm{~h}$ analysis of home cage activity, although increased motor activity was observed during the dark phase of the first $24 \mathrm{~h}$ (arrow). (B) No difference between $\mathrm{Y} 2 / \mathrm{Y} 4$ double $\mathrm{KO}$ and $\mathrm{Y} 2^{\text {lox/lox }}$ mice was apparent in cumulative $24 \mathrm{~h}$ home cage activity, but an increased agitation was seen during and shortly before the onset

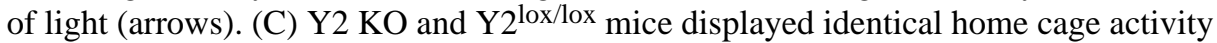
(number of animals per group: eight). 
Exp. 1

Exp. 2
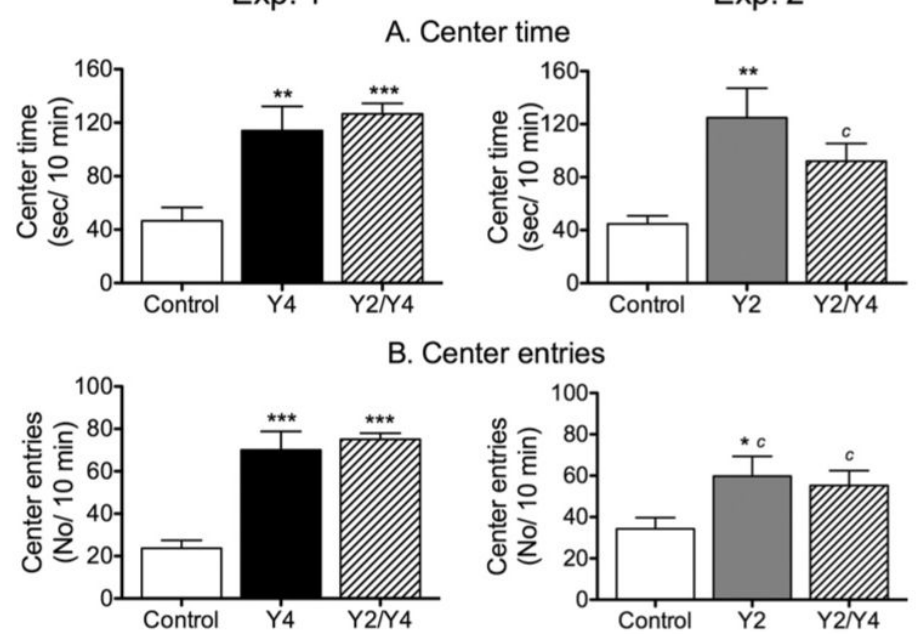

C. Total distance
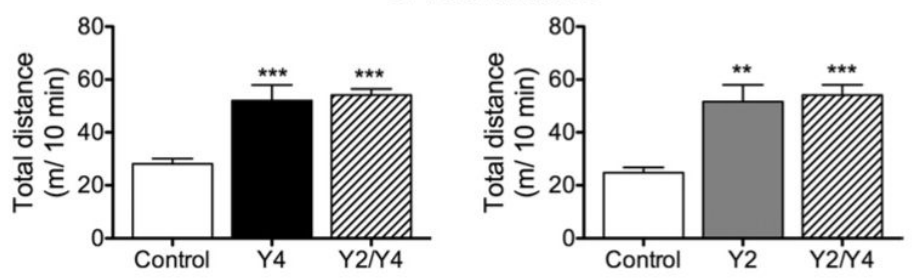

Fig. 3.

Open field test. (A) The time spent in the center of the arena was significantly increased in $\mathrm{Y} 2 \mathrm{KO}$ and $\mathrm{Y} 4 \mathrm{KO}$ and $\mathrm{Y} 2 / \mathrm{Y} 4$ double KO mice. (B) Higher number of center entries and (C) increased distance traveled was seen under stressful conditions in all three genotypes (Y2 KO, Y4 KO and Y2/Y4 double-KO) when compared with control. Analysis was done by one-way ANOVA and Newman-Keuls post hoc test. * $P<0.05$, ** $P<0.01$, *** $P<0.001$ vs. controls ( $n=8-10$ mice per genotype); ${ }^{c} P<0.001$ after pooling Y2/Y4 KO mice and controls from both experiments ( $n=12-16$ mice per genotype). 
Exp. 1

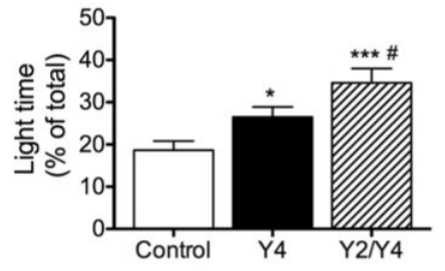

B. Light distance
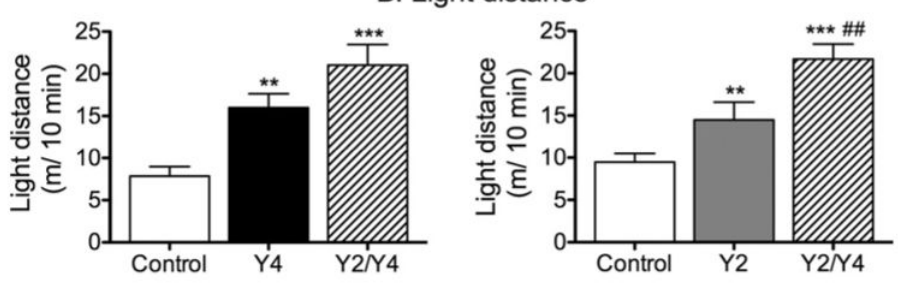

C. Dark distance
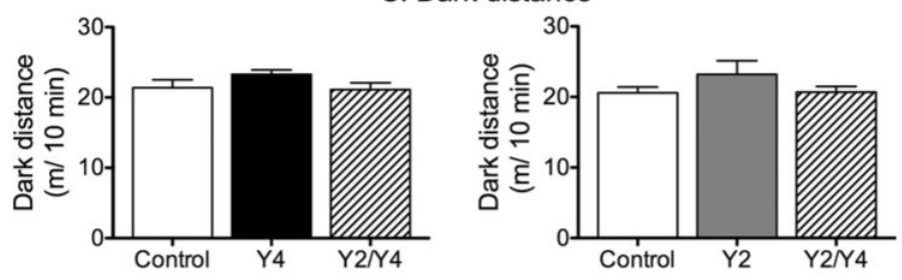

Fig. 4.

Light/dark test. (A) In the light/dark test $\mathrm{Y} 4 \mathrm{KO}, \mathrm{Y} 2 \mathrm{KO}$ and $\mathrm{Y} 2 / \mathrm{Y} 4$ double $\mathrm{KO}$ mice spent significantly more time in the light compartment compared with controls and $\mathrm{Y} 2 / \mathrm{Y} 4 \mathrm{KO}$ spent significantly more time in the light compartment than Y4 KO. (B) Y4 KO, Y2 KO and $\mathrm{Y} 2 / \mathrm{Y} 4 \mathrm{KO}$ mice had a higher distance traveled in the light compartment than controls, and $\mathrm{Y} 2 / \mathrm{Y} 4 \mathrm{KO}$ showed a higher light distance than Y2 KO mice. (C) There was no difference in dark distance in any genotype. One-way ANOVA and Newman-Keuls post hoc test, * $P<0.05$, ** $P<0.01$, *** $P<0.001$ significantly different vs. controls, ${ }^{\#} P<0.05,{ }^{\#} P<0.01$ significantly different vs. single KO mice ( $n=10-15$ mice per genotype). 
Exp. 1

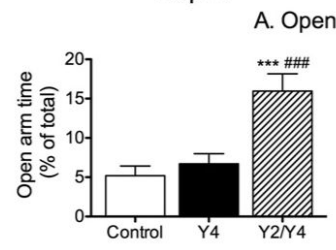

B. Open arm entries
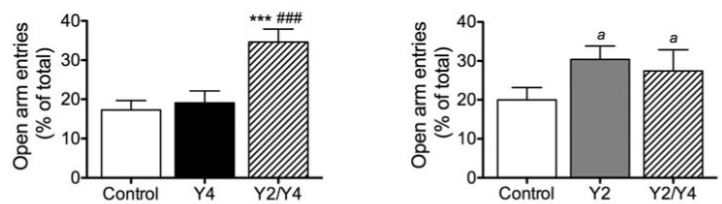

C. Closed arm entries
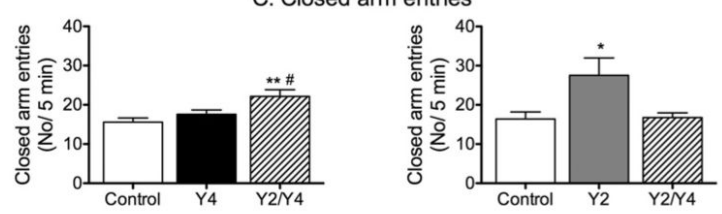

D. Total distance
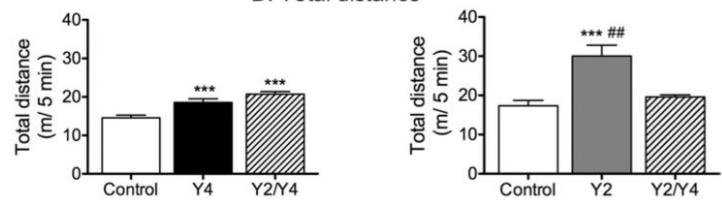

Fig. 5.

Elevated plus maze. (A) In the elevated plus maze Y2 KO and Y2/Y4 double-KO spent more time on the open arms compared with controls. (B) Increased percentage of open arm entries in $\mathrm{Y} 2$ and $\mathrm{Y} 2 / \mathrm{Y} 4 \mathrm{KO}$ mice compared with controls and $(\mathrm{C})$ higher number of closed arm entries in $\mathrm{Y} 2 \mathrm{KO}$ mice compared with controls and Y2/Y4 KO mice compared with Y4 $\mathrm{KO}$ and controls. (D) Increased total distance traveled in $\mathrm{Y} 2$, Y4 and $\mathrm{Y} 2 / \mathrm{Y} 4 \mathrm{KO}$ mice. Analysis was done by one-way ANOVA and Newman-Keuls post hoc test. * $P<0.05$, ** $P<0.01$, *** $P<0.001$ significantly different vs. controls, ${ }^{\#} P<0.05$, \#\# $P<0.001$ significantly different vs. Y4 KO ( $n=14-19$ mice per genotype) a $P<0.05$ (significance only after pooling controls and Y2/Y4 mice from both experiments). 

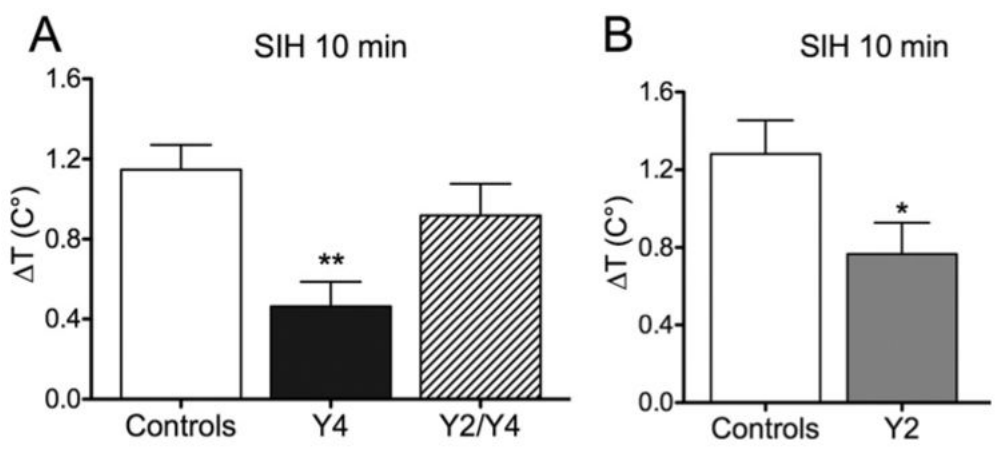

Fig. 6.

Stress-induced hyperthermia. (A) Reduction in stress-induced hyperthermia in Y4 KO mice compared with controls and (B) reduced stress-induced hyperthermia in Y2 KO mice. * $P<0.05$, ** $P<0.01$, significantly different vs. controls ( $n=12-15$ per genotype). 

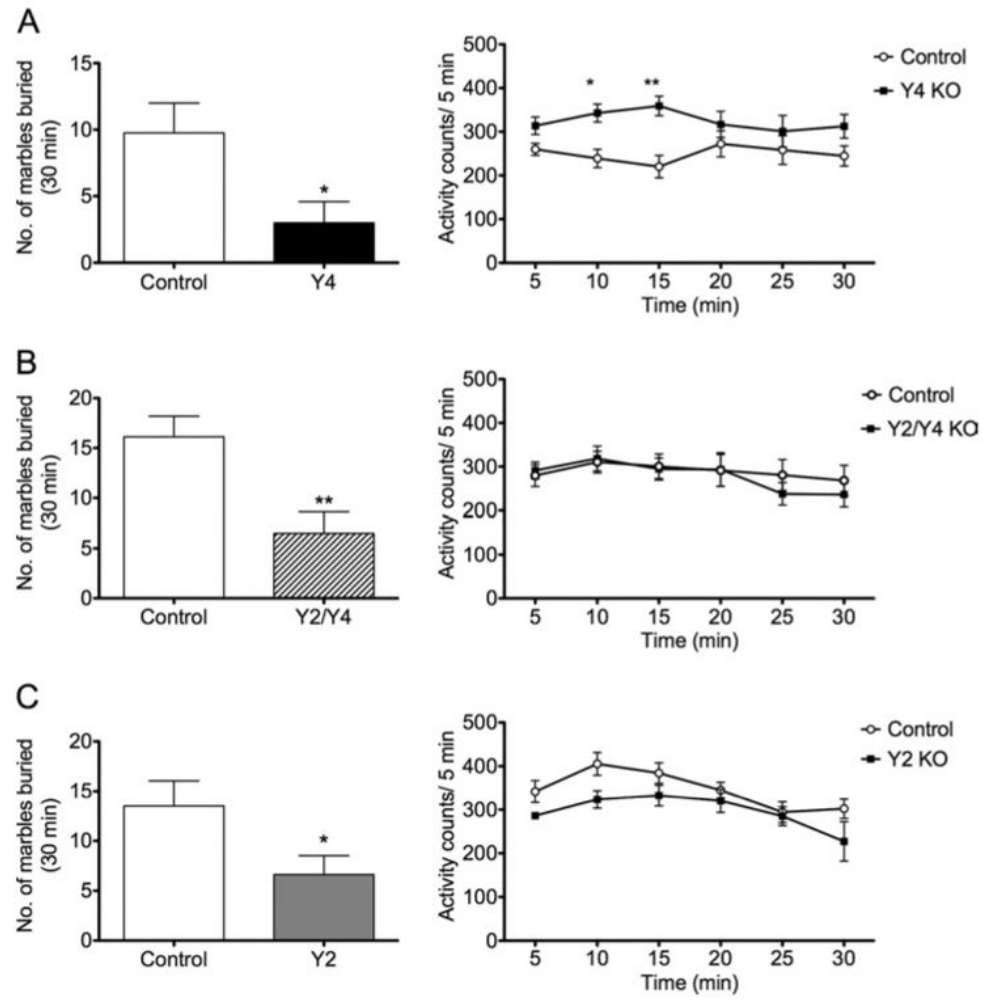

Fig. 7.

Defensive marble burying. (A) Reduced number of marbles buried and increased activity in the first 15 min of 30 min testing period in $\mathrm{Y} 4 \mathrm{KO}$ mice. (B) Reduction of number of marbles buried and unaltered activity in Y2/Y4 double KO mice. (C) Decreased number of marbles buried in $\mathrm{Y} 2 \mathrm{KO}$ mice and no change in activity compared with controls. ${ }^{*} P<0.05$, ** $P<0.01$ significantly different vs. controls, Student's $t$-test for number of marbles buried, two-way ANOVA and Bonferroni post hoc test for activity counts ( $n=8$ per genotype). 
Exp. 1

A. Forced swim test

Exp. 2
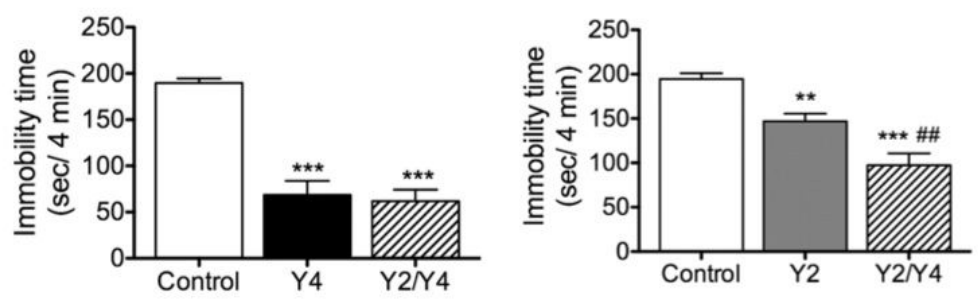

B. Tail suspension test
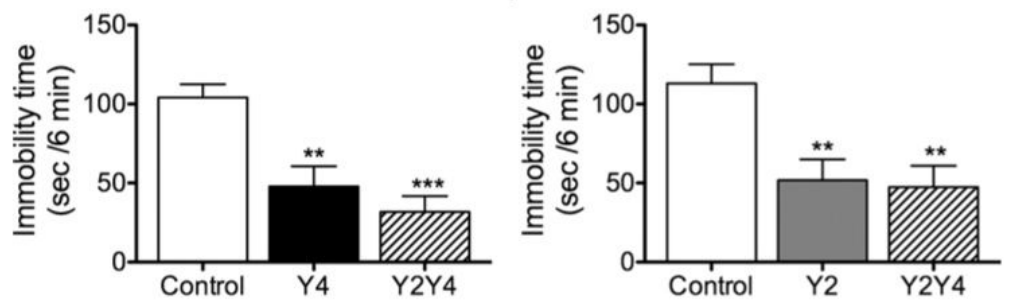

Fig. 8.

Porsolt forced swim test and tail suspension test. (A) In the forced swim test the time spent floating was significantly reduced in $\mathrm{Y} 2 \mathrm{KO}, \mathrm{Y} 4 \mathrm{KO}$ and $\mathrm{Y} 2 / \mathrm{Y} 4$ double $\mathrm{KO}$ mice. (B) Similarly, Y2 KO, Y4 KO and Y2/Y4 double KO show a significant reduction in immobility time in the tail suspension test, when compared with controls. Analysis was done by oneway ANOVA and Newman-Keuls post hoc test. * $P<0.05, * * P<0.01, * * * P<0.001$ significantly different vs. control, ${ }^{\# \#} P<0.001$ different from Y2 KO ( $n=8-10$ mice per genotype). 

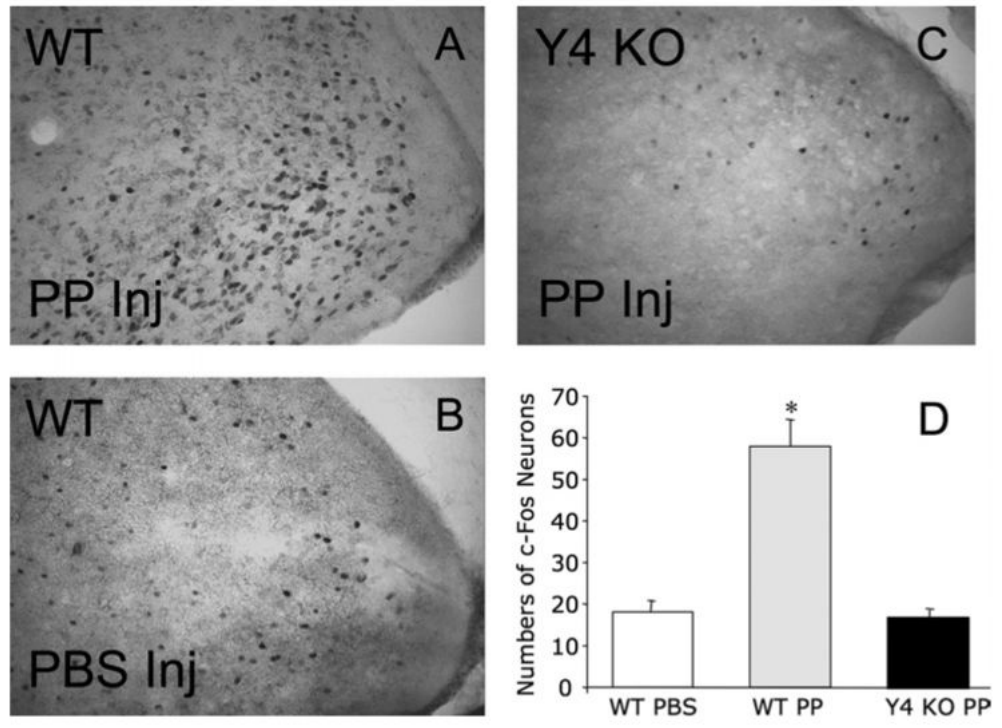

Fig. 9.

c-Fos activation in the mouse brain after i.p. injection of PP (1.0 mg/kg). (A) High levels of c-Fos positive neurons could be found in the medial amygdala area $30 \mathrm{~min}$ after systemic PP administration and only background staining is observed in (B) saline-injected control mice or (C) PP-injected Y4 receptor KO mice. (D) Statistical analysis after counting positive neurons in this area. Scale bar $=40 \mu \mathrm{m} . N=4-6$ mice, $* P<0.001$. 


\section{Table 1}

Relative change in c-Fos immunoreactivity in regions of the brain at 30 and 90 min after i.p. injection of PP in mice $(1.0 \mathrm{mg} / \mathrm{kg})$

\begin{tabular}{lll}
\hline & 30 min & 90 min \\
\hline ARC & ++ & + \\
PVN & + & +++ \\
VMHDM & ++ & +++ \\
LHA & + & ++ \\
NTS & +++ & + \\
AP & +++ & + \\
MeA & +++ & + \\
\hline
\end{tabular}

ARC, arcuate nucleus of the hypothalamus; PVN, paraventricular nucleus of the hypothalamus; VMHDM, ventromedial hypothalamus dorsomedial aspect; LHA, lateral hypothalamic area; NTS, nucleus tractus solitarus; AP, area postrema. 